\title{
KONSEP HORACE DALAM NOVEL LASKAR PELANGI KARYA ANDREA HIRATA KAJIAN KRITIK SASTRA
}

\author{
Adhitia Rizky ${ }^{1}$, Afifah Yasmin Larasati ${ }^{2}$ \\ Program Studi Sastra Inggris Fakultas Adab dan Humaniora \\ Universitas Islam Negeri Sunan Gunung Djati Bandung \\ Surel: adhitiarizky015@gmail.com ${ }^{1}$ \\ Afifahyasmin99351@gmail.com²
}

\begin{abstract}
Abstrak
Karya cipta manusia baik lisan maupun tulisan dapat dikategorikan sebagai sastra. Salah satu jenis sastra yaitu prosa yang terbagi menjadi dua jenis yaitu prosa lama dan baru. Novel adalah salah satu jenis prosa baru yang populer dan kini menjadi objek penelitian yang menarik untuk dikaji. Salah satu novel yang terkenal berjudul Laskar Pelangi karya Andrea Hirata. Penelitian ini menggunakan metode deskriptif kualitatif yang mana diharapkan peneliti mampu menjabarkan menggunakan katakata dan bahasa. Data yang digunakan diambil dari 2 sampel kutipan dari narasi narator lalu dilakukan dengan membandingkan teori dan objek kajian. Teori yang digunakan dalam penelitian ini adalah Teori Kritik Sastra karya Horace yaitu Utile et Dulce yang mana memiliki arti bahwa karya sastra yang baik adalah meliputi nilai estetika dan nilai moral. Adapun hasil yang diperoleh dalam penelitian ini yaitu terdapat korelasi antara teori sastra Horace-Utile et Dulce dengan Novel Laskar Pelangi karya Andrea Hirata. Novel ini juga mampu mempresentasikan nilai estetika dan nilai moral.
\end{abstract}

Kata Kunci : Laskar pelangi, Utile et Dulce, dan kritik sastra.

\section{Abstract}

Human works both oral and written can be categorized as literature. One type of literature is prose which is divided into two types namely old and new prose. Novels are a popular type of new prose and are now become interesting research objects to study. One of the famous novels titled Laskar Pelangi by Andrea Hirata. This research uses a qualitative deseriptivel method which iscexpected to be able to describe using words and language. The data used is taken from 2 sample quoting from the narrator's narration and then carried out by comparing the theory and object of study. The theory used in this study is Horace's Literary Criticism, Utile et Dulce which means that good literary works include aesthetic values and moral values. The results in this study are that there is a correlation between the literary theory of Horace-Utile et Dulce with Laskar Pelangi novel by Andrea Hirata. This novel is also able to present aesthetic values and moral values.

Keywords : Laskar Pelangi, Utile et Dulce, and Literary Criticism. 


\section{PENDAHULUAN}

Karya cipta manusia baik lisan maupun tulisan dapat dikategorikan sebagai sastra. Sastra berasal dari bahasa Sansekerta 'Shastra' yang terbentuk dari kata sas yang memiliki arti 'ajaran' atau 'instruksi'. Seiring perkembangan zaman, sastra semakin mendewasa dan mulai berkembang dengan baik. Salah satu jenis karya sastra Indonesia yang berkembang adalah prosa. Berdasarkan jenisnya prosa terbagi menjadi dua bentuk yaitu prosa lama dan prosa baru. Prosa lama terdiri dari dongeng, hikayat, dan sejarah sedangkan prosa baru terdiri dari roman, novel, dan puisi.

Novel adalah salah satu jenis prosa baru yang sangat populer saat ini. Novel adalah sebuah karya fiksi yang menyajikan sebuah model kehidupan yang ideal, imajinatif, serta membangun unsur intrinsik seperti tokoh, penokohan, plot, dan sudut pandang yang dikiaskan oleh penulis sehingga seolah-olah cerita tersebut tampak seperti realita dunia yang benar-benar terjadi (Nurgiyanto, 2010: 70).

Novel menjadi objek yangesia don menarik untuk dikaji dan dianalisis menggunakan metode kritik sastra. Kritik sastra adalah sebuah hasil dari usaha membaca dalam mencari dan juga menentukan nilai karya sastra melewati pemahaman berikut dengan penafsiran secara sistematik dan juga tertulis (Hardjana, 1981: 123).
Teori kritik sastra yang menjadi acuan dalam jurnal ini adalah teori yang dikemukakan oleh Horace yaitu Utile et Dulce yang mana memiliki arti bahwa karya sastra yang baik adalah karya sastra yang memuat unsur menyenangkan sekaligus memberikan manfaat (Badrun, 1983: 73).

Teori ini berasal dari bahasa Latin yaitu Utile yang memiliki arti usefulness atau kegunaan sedangkan kata Dulce memiliki arti enjoyment atau dalam bahasa Indonesia memiliki arti kesenangan. Teori ini mengatakan bahwa dalam setiap karya sastra pasti memberikan manfaat atau sebuah pembelajaran setelah karya sastra tersebut dibaca.

Dalam karya sastra, penulis pasti memiliki pesan, saran bahkan pembelajaran baik yang tersirat maupun tersurat dalam karyanya. Hal ini digunakan sebagai ajang edukasi bagi para pembaca, sehingga karya sastra mampu untuk membentuk masyarakat.

Karya sastra memiliki kedudukan yang kuat dalam kemasyarakatan, sastra menggunakan bahasa sebagai mediumnya yang mana merupakan hasil cipta sosial dalam lembaga sosial (Wellek dan Warren, 1976: 94). Maka, karya sastra yang baik adalah yang mampu untuk digunakan sebagai media pembelajaran baik berupa pelajaran moral maupun pelajaran hidup.

Dulce dalam karya sastra dapat berupa pandangan estetika baik dari segi alur, gaya bahasa ataupun 
penggambaran perasaan yang baik dari penulis. Penggambaran perasaan ini bukan hanya tentang perasaan bahagia saja akan tetapi dapat meliputi penggambaran perasaan akan kesedihan, kekesalan, keraguan bahkan kemarahan. Dulce atau yang biasa disebut to delight ini juga dapat berarti bahwa penulis mampu untuk memberikan kesan penulisan dengan diksi yang baik dan membuat para pembaca tertarik dibuatnya.

Berdasarkan teori tersebut sastra berkaitan langsung dengan nilai estetika sekaligus nilai manfaat dan salah satunya dapat ditemukan pada Novel terkenal yang diterbitkan pada tahun 2005 oleh berjudul Laskar Pelangi karya Andrea Hirata. Novel ini memiliki 382 halaman yang terbagi menjadi 34 bab. Dalam hal ini peneliti membatasi dengan menggunakan 2 sampel yaitu narasi yang disampaikan oleh narator

Masalah dalam penelitian ini adalah untuk meninjau, menelaah dan juga menganalisis hubungan antara teori kritik sastra Horace dengan novel Laskar Pelangi melalui pendekatan pragmatik. Adapun pengungkapan unsur-unsur intrinsik seperti lrplot termasuk peran narator di dalamnya untuk dijadikan bahan penguat teori sastra ini. Peneliti menggunakan teori kritik sastra dengan metode deskriptif kualitatif.

Metode ini adalah suatu metode yang digunakan sebagai penggambaran dan analisis atas suatu hasil penelitian namun tidak digunakan sebagai bahan membuat sebuah kesimpulan yang lebih luas (Sugiyono, 2005: 154). Sehingga dalam hal ini peneliti diharapkan mampu untuk mengunggapkan dalam bentuk tulisan dan bahasa.

Tujuan penelitian ini adalah untuk mendeskripsikan korelasi antara teori kritik sastra Horace yaitu Utile et Dulce yang terkandung dalam Novel Laskar Pelangi karya Andrea Hirata.

\section{METODE}

Pengkajian novel Laskar Pelangi karya Andrea Hirata ini menggunakan metode dekriptif kualitatif. Untuk mendapatkan nilai moral dan nilai estetik maka dilakukan penelaahan terhadap bacaan novel tersebut. Subjek penelitian ditujukan terhadap petikan kalimat-kalimat dalam novel yang dianggap memenuhi konsep to teach and to delight. Adapun teknik pengumpulan data yang digunakan dalam kajian ini sebagai berikut.

1. Studi pustaka digunakan untuk memperkaya serta meyakinkan pembaca terhadap teori-teori yang disajikan dalam kajian ini. Teoriteori tersebut didapatkan artikelartikel jurnal maupun buku referensi.

2. Memperdalam bacaan menggunakan metode observasi. Dalam menemukan penggambaran konsep Horace, maka dilakukan penelaahan terhadap novel Laskar Pelangi itu sendiri. 
3. Pengumpulan kutipan yang dianggap perlu untuk dimasukan ke dalam kajian ini dilakukan dengan wawancara terhadap dosen. Informasi itu dilakukan untuk memperoleh informasi tentang pandangan para dosen terhadap tulisan dalam novel.

\section{HASIL DAN PEMBAHASAN}

\section{Konsep Horace dalam Novel Laskar Pelangi Karya Andrea Hirata}

Sastra yang merupakan cabang dari seni telah menjadi suatu unsur yang tidak terpisah dari kehidupan manusia. Usia yang cukup tua menjadi salah satu daya tarik dari sastra itu sendiri. sebagai penikmat sastra kita telah sering mendengar banyak karya sastra sejak kita lahir tanpa kita sadari salah satunya adalah dongeng.

Nama genre untuk penyebutan sebuah karya sastra tentu memiliki keunikan masing-masing di setiap negara. Di Indonesia terdapat banyak genre karya sastra yang sering kita dengar sehari-hari antara lain: mantra, pantun, dongeng, balada, dan mite dalam kehidupan sehari-hari (Badrun, 1983: 72).

Novel adalah karya sastra bergenre prosa yang merupakan sebuah konstruksi baru untuk cerita pendek. Di Indonesia salah satu karya sastra prosa terbaik yaitu novel Laskar Pelangi. Sebuah karya sastrawan kontemporer yang bertemakan tentang perjuangan seorang anak yang ingin menempuh kehidupan dan citacitanya dengan belajar sungguhsungguh.
Novel ini bercerita tentang sebuah persahabatan yang sangat solid karena pernah merasakan kehidupan yang susah bersama-sama. Sudut pandang yang digunakan dalam novel tersebut itu sendiri menggunakan orang pertama yaitu "aku" yang mengarah kepada seorang anak yang kerap dipanggil Ikal. Kehidupan yang susah serta kondisi masyarakat yang termarjinalkan dari kampung halamannya karena tereksploitasi oleh perusahaan negara membuat mereka tumbuh menjadi orang yang hebat.

Sastra merupakan hal yang menarik untuk diketahui. Dalam pendeskripsiannya, sastra mempunyai elemen-elemen yang berfungsi untuk menjabarkan segala hal yang berkaitan dengan karya itu sendiri. Elemen-elemen tersebut adalah elemen intrinsik dan ekstrinsik.

Elemen intrinsik digunakan untuk mengetahui segala hal yang berkaitan dengan tema, tokoh dan penokohan, alur, setting dan amanat yang terkandung. Sedangkan elemen ekstrinsik digunakan untuk mengetahui unsur pendukung dari penulis itu sendiri seperti latar belakang penulis, sosial budaya dan kondisi masyarakat yang disebutkan karya sastra tertentu (Hardjana, 1981: 65).

Pada saat ini sastra tidak lagi dikenal sebagai sesuatu yang dipelajari untuk seseorang yang memiliki jiwa seni yang tinggi. Semua orang dapat mempelajari sastra dimanapun baik dalam diskusi bebas, seminar atau pun workshop yang sering diadakan pihak tertentu. 
Melihat peristiwa tersebut bisa dilihat bahwa sastra tidak lagi menjadi ilmu untuk orang tertentu melainkan sebuah studi ilmu yang diakui dan banyak dipelajari salah satunya teori sastra.

Horace merupakan seorang filsuf dan seorang penyair kerajaan pada zaman Julius Caesar dan Augustus atau Octavian. Dalam teorinya ia berpendapat bahwa sebuah karya sastra itu tidak lain untuk membuat sebuah kesan dan pesan serta memberi pendidikan kepada pembacanya. Dalam buku Introduction to Criticism karya Dian Nurrachman disebutkan bahwa Horace lebih menekankan bagaimana sebuah karya itu dapat to delight and instruct an intelligent reader yang mana didapatkannya dari penggabungan teori sastra Plato dan Aristoteles (Nurrachman, 2017: 73).

Sebuah karya sastra dikatakan sangat bermanfaat jika telah memenuhi syarat umum yaitu to teach and to delight. Makna, umum dari pengertian itu sendiri adalah sebuah karya sastra itu dapat dikatakan sempurna jika dapat memberikan sebuah novelty dalam penulisannya. Pembaharuan itu adalah dengan menggunakan sebuah gaya bahasa dalam pengungkapan sebuah peristiwa.

Karya sastra yang menggunakan gaya bahasa akan terlihat lebih nyaman untuk dibaca sehingga pembaca tidak hanya membaca sebuah karya yang monoton dengan gaya bahasa yang kaku. Seperti yang dikutip dalam novel Laskar Pelangi ini yang merupakan salah satu contoh dari to delight.

"Awan-awan kapas berwarna biru lembut turun. Mengapung rendah ingin menyentuh permukaan laut yang surut jauh, beratus-ratus hektar luasnya, hanya setinggi lutut, meninggalkan pohon-pohon kelapa yang membujur di sepanjang Pantai Tanjong Kelayang. Aku tahu bahwa awan-awan kapas biru muda itu dapat menjadi penghibur bagi mataku, tapi dia tak kan pernah menjadi sahabat bagi jiwaku, karna sejak minggu lalu aku telah menjadi sekuntum daffodil yang gelisah, sejak ku kenal sebuah kosa kata baru dalam hidupku: rindu" (Hirata, 2005: 187).

Dalam kutipan di atas merupakan salah satu contoh dari teori Dulce atau lebih dikenal dengan to delight yang mana terdapat sebuah pembaharuan dalam pengungkapan sebuah perasaan rindu.

Dalam kutipan ini penulis berusaha untuk menggambarkan atau mengungkapkan perasaan dari tokoh "aku" yang mana merasakan perasaan rindu dengan menggunakan sudut pandang orang pertama sebagai tokoh utama yang memiliki kerinduan. Dalam hal ini kutipan tersebut dapat membuat astr pembaca seakan-akan terbawalke dalam alur cerita dan ikut merasakan apa yang tokoh "aku" alami. Penulis telah memenuhi salah satu syarat untuk sebuah karya sastra yang dianggap oleh Horace sempurna yaitu memberikan teori Dulce yang mana dapat memberikan gambaran perasaan rindu yang baik dalam kutipan karya sastra tersebut.

Penginterpretasian pembaca dalam sebuah karya sastra yang 
banyak menggunakan gaya bahasa merupakan keberhasilan sebuah karya sastra untuk membuat seorang pembaca more intelligent karena mendapatkan sebuah pesan tersirat yang terkandung dalam karya tersebut. Maka, novel Laskar Pelangi ini dikatakan telah memenuhi dua syarat utama.

Dalam mewujudkan konsep Utile et Dulce Horace mendeskripsikan beberapa syarat yang salah satunya harus dipenuhi oleh semua penulis karya sastra. Persyaratan ini disebut dengan poetic license. Horace menegaskan bahwa seseorang tidak dapat semena-mena menjadi seorang penulis karya sastra.

Persyaratan-persyaratan tersebut adalah sebagai berikut.

1) Responsibility, seorang penulis haruslah tidak melebihi kapasitas yang ia miliki.

2) Novelty, seorang penulis mampu untuk mengungkapkan sesuatu dengan cara yang baru.

3) Suitability, penulis harus mampu menyesuaikan bahasa, zaman, genre dan konsistensi.

4) Beautiful and affecting, penulis harus memiliki perasaan terlebih dahulu sehingga tulisannya mampu untuk mempengaruhi pembaca (Nurrachman, 2017: 73).

Syarat poetic license $\mathrm{di}$ atas meruapakan patokan untuk seorang penulis yang Horace ungkap. Dalam sebuah karya sastra boleh jadi hanya menggunakan salah satu saja. Dengan demikian dapat tercapai konsep Utile et Dulce.
"Hari ini aku belajar bahwa setiap orang, bagaimana pun terbatas keadaannya, berhak memiliki citacita, dan keinginan yang kuat untuk mencapai cita-cita itu mampu menimbulkan prestasi-prestasi lain sebelum cita-cita sesunguhnya tercapai. Keinginan kuat itu juga memunculkan kemampuankemampuan besar yang tersembunyi dan keajaiban-keajaiban di luar perkiraan" (Hirata, 2005: 282).

Dalam kutipan di atas dapat ditemukan salah satu teori milik Horace yaitu Utile atau to teach. Hal ini tergambarkan bahwa penulis berusaha untuk memberikan sebuah pesan kepada para pembaca yang mana pembaca mampu untuk mendapatkan pembelajaran dari kutipan tersebut.

Salah satunya adalah bahwa setiap manusia berhak untuk memiliki mimpinya sendiri terlepas individu tersebut tidak mampu atau memiliki keadaan yang terbatas. Maka, bermimpilah setinggi-tingginya lalu berprestasilah, namun hal ini bukanlah sebuah pemberian Tuhan belaka melainkan sebuah usaha dan juga mengasah kemampuan yang dimiliki.

Jadi, dalam kutipan di atas penulis berusahá memberikan pesan terhadap pembaca yaitu sebagai manusia haruslah memiliki cita-cita atau mimpi, namun hal ini bukan saja hanya diangan atau kemauan saja akan tetapi juga harus didukung dengan usaha yang besar yaitu dengan belajar dan berlatih. 


\section{PENUTUP}

\section{Simpulan}

Novel Laskar Pelangi karya Andrea Hirata merupakan karya sastra yang sangat populer di Indonesia. Andrea begitu lihai dalam mengungkapan sebuah peristiwa demi peristiwa menggunakan gaya bahasa dan diksi pilihannya. Dalam konsep yang digagas Horace sebuah karya sastra yang baik haruslah memuat Utile et Dulce.

Konsep Utile et Dulce yang digagas oleh Horace artinya to teach and to delight. Konsep tersebut berjalan lurus dengan konsep nilai moral dan estetika yang tergambarkan pada kutipan dari Novel Laskar Pelangi karya Andrea Hirata. Maka, dapat dikatakan bahwa novel ini memuat teori Horace yang mana menyajikan unsur penghibur dan memberikan manfaat bagi para pembaca.

\section{DAFTAR PUSTAKA}

Badrun, Ahmad. 1983. Pengantar Sebuah Sastra. Surabaya: Usaha Nasional.

Hardjana, Andre. 1981. Kritik Sastra!nesia dan Daerah

Sebuah Pengantar. Jakarta: Gramedia.

Hirata, Andrea. 2005. Laskar Pelangi. Yogyakarta: Bentang Pustaka.

Nurgiyantoro, B. 2010. Pembelajaran penilaian Bahasa. Yogyakarta: BPFE.

Nurrachman, Dian. 2017. Introduction to Criticism. Bandung: Pustaka Aura Semesta.

\section{Sugiyono. 2005. Penelitian \\ Administrasi. Bandung : Alfabeta.}

